\title{
DINAMIKA SANDUNG DI HULU SUNGAI KAHAYAN
}

\section{THE DINAMICS OF SANDUNG IN THE HEADWATERS OF KAHAYAN RIVER}

\author{
Sunarningsih \\ Balai Arkeologi Banjarmasin, Jalan Gotong Royong II, RT 03/06, Banjarbaru 70711, Kalimantan Selatan; \\ email:asihwasita@yahoo.com
}

\begin{abstract}
Abstrak. Daerah Aliran Sungai (DAS) Kahayan mengalir di wilayah Provinsi Kalimantan Tengah dan bermuara di Laut Jawa. Di sepanjang DAS Kahayan ini bermukim masyarakat Ngaju yang menjadi mayoritas. Sandung merupakan bangunan kubur yang digunakan oleh masyarakat Ngaju dari dulu hingga sekarang. Tulisan ini akan membicarakan penggunaan sandung dan perubahannya pada masyarakat Ngaju di hulu DAS Kahayan. Metode yang digunakan adalah deskriptif eksplanatif. Data yang digunakan diperoleh melalui survei dan wawancara yang dilakukan pada 2013. Selain itu, juga dilakukan penelusuran terhadap data pustaka untuk membantu dalam analisis dan interpretasi. Dari data yang didapatkan dan hasil analisis yang telah dilakukan dapat diketahui bahwa perubahan terjadi pada penggunaan sandung sebagai tempat kubur sekunder oleh masyarakat Ngaju, terlihat pada letak, bentuk, pemilihan bahan, dekorasi (motif hias), dan konsep. Hal tersebut disebabkan oleh perubahan tata cara hidup (bermukim), ketersediaan bahan baku di lingkungan sekitar, perubahan cara pandang masyarakat terhadap keberadaan sandung, perubahan kepercayaan keluarga si mati yang menyediakan bahan pembuatan sandung, dan perubahan tren.
\end{abstract}

Kata kunci: sandung, penguburan sekunder, Ngaju, Sungai Kahayan, Kalimantan Tengah

\begin{abstract}
Kahayan watershed flows in theregion of Central Kalimantanan disembogues into the Java Sea. Along the Kahayan are settled the major communities, Ngaju. They build sandung, a secondary burial that has been used by the publicfrom the past until present. This paper discusses the use of sandung and its changes, to the Ngaju community in the watershed flows Kahayan. The method used is descriptive explanative. Meanwhile, data were obtained by archaeological survey and interview conducted by Balai Arkeologi Banjarmasin in 2013. Analysis and interpretation processes will be completed by adding data from literature. The results depict that the changes in the use of sandung as a secondary burial of Ngaju society are location, shape, material selection, decoration, and concepts. Those are caused by the changes of their living, basic materials in their surroundings, the family's belief of the dead, and trend.
\end{abstract}

Keywords: sandung, secondary burial, Ngaju, Kahayan River, Kalimantan Tengah

\section{PENDAHULUAN}

Dinamika menurut Kamus Besar Bahasa Indonesia (Tim Penyusun Kamus Pusat Pembinaan dan Pengembangan Bahasa 1995: 234) adalah kelompok gerak atau kekuatan yang dimiliki sekumpulan orang dalam masyarakat yang dapat menimbulkan perubahan dalam tata hidup masyarakat yang bersangkutan. Sebagai sebuah masyarakat dengan hasil kebudayaannya, Ngaju yang berada di wilayah Kalimantan Tengah juga memiliki dinamika dalam kehidupannya. Adapun definisi dari kebudayaan menurut Koentjaraningrat (2009: 144), yaitu sebagai sebuah sistem gagasan, tindakan, dan hasil karya manusia dengan cara belajar untuk kehidupan masyarakat. Selanjutnya, menurut Parsudi Suparlan, kebudayaan dianggap sebagai keseluruhan pengetahuan yang dimiliki manusia sebagai makhluk sosial, yang berisi perangkat model pengetahuan yang dapat digunakan untuk memahami dan menginterpretasi lingkungan yang dihadapi, sehingga tercipta tindakan yang diperlukan (Alam 1998: 2). Tujuh unsur kebudayaan adalah bahasa, sistem pengetahuan, organisasi sosial, sistem peralatan hidup dan teknologi, sistem mata pencaharian hidup, sistem religi, dan kesenian (Koentjaraningrat 2009: 165). Tiap unsur tersebut diwujudkan dalam ide, gagasan, nilai; aktivitas/ 
tindakan; dan artefak atau benda hasil karya (Koentjaraningrat 2009: 150). Simbol dan konsep dalam kebudayaan bersifat cair dan dinamis, dan keberadaannya tergantung pada praksis para pelakunya. Dengan demikian, kebudayaan terwujud sebagai proses interaksi timbal balik antara pelaku dan simbol budaya, dan kebudayaan berfungsi sebagai konsep bagi tindakan pelaku yang menjadi bahan pertimbangan dalam menentukan tindakan (Alam 1998: 5). Simbol sendiri dapat dijumpai dalam sebuah ritual, yang sebenarnya merupakan bagian terkecil dari ritual yang masih menyisakan sifat spesifik dari perilaku ritual tersebut (Turner 1967: 19).

Oleh karena sifatnya yang dinamis, kebudayaan selalu berubah. Kebudayaan yang tampaknya asli ternyata merupakan hasil konstruksi sosial yang mengacu kepada kebudayaan asing (Alam 1998: 7). Proses globalisasi dan perubahan budaya tidak pernah berhenti, sejak dulu dapat diamati dengan jelas, misalnya pada zaman Kerajaan Sriwijaya, Majapahit, dan zaman kolonial yang kebudayaannya dipengaruhi oleh unsur-unsur mancanegara (Alam 1988: 8).

Salah satu unsur kebudayaan, yaitu religi atau kepercayaan menyediakan berbagai informasi yang diperlukan oleh pengikutnya untuk menjawab berbagai masalah yang mendasar tentang arti dari kehidupan dan kematian, dan penyebab segala kejadian (Harris 1997: 368). Oleh karena itu, kepercayaan yang dimiliki oleh kelompok masyarakat akan sangat berpengaruh terhadap ritual yang dilakukan, baik dalam daur kehidupan maupun daur kematian.

Salah satu bagian dari upacara daur kematian adalah sandung, bangunan kubur sekunder masyarakat Ngaju. Ngaju adalah salah satu suku asli Kalimantan yang banyak bermukim di sepanjang sungai, yaitu di hilir dan sebagian wilayah tengah Sungai Barito, Daerah Aliran Sungai Kapuas, Daerah Aliran Sungai Kahayan. Daerah Aliran Sungai Kahayan berada di wilayah Provinsi Kalimantan Tengah (Sellato 1989: 7 dan 20-21). Sungai ini mengalir dari hulu ke hilir, dan bermuara di Laut Jawa, melalui beberapa kabupaten, antara lain Kabupaten Gunung Mas,
Kotamadya Palangkaraya, dan Kabupaten Pulang Pisau. Ngaju sendiri berarti "uplander", orang yang tinggal di tanah yang tinggi, dan tepian Sungai Kahayan merupakan daerah asal mula mereka sebelum akhirnya menyebar melalui sungai (Schärer 1963: 1-2). Masyarakat Ngaju merupakan salah satu dari suku Dayak lainnya yang menggunakan bahasa Ngaju untuk bertutur dalam bahasa sehari-hari.

Penelitian terhadap kehidupan masyarakat Ngaju sudah banyak dilakukan, baik oleh peneliti Indonesia, maupun peneliti asing. Rampai (1985: 888-894) telah mengkaji sandung sebagai makam sekunder melalui pendekatan etnoarkeologi. Penelitian yang dilakukan oleh Balai Arkeologi Banjarmasin terhadap ritual penguburan masyarakat Ngaju (tiwah) juga sudah dilakukan, antara lain di Pendahara, sebuah desa di tepi Sungai Katingan, Kalimantan Selatan (Sulistyanto 2004: 20-39), sedangkan survei bangunan kubur (sandung) antara lain di Kotawaringin Timur (Hartatik 2000: 14-29). Keragaman bentuk sandung banyak menjadi bahan kajian, tetapi perubahan seiring dengan perkembangan zaman dalam pendirian sandung masih belum banyak diperbincangkan.

Oleh karena itu, dalam artikel ini akan diuraikan keberadaan bangunan sandung yang berada di hulu Sungai Kahayan. Permasalahan yang diajukan adalah:

1. Perubahan apa saja yang terjadi pada penggunaan sandung oleh masyarakat Ngaju dari hulu Daerah Aliran Sungai Kahayan?

2. Faktor apa saja yang mempengaruhi terjadinya perubahan tersebut?

\section{METODE}

Dalam ilmu antropologi, untuk mengkaji dinamika budaya diperlukan pendekatan prosesual (Winarto 1999: 26), yaitu sebuah pendekatan yang dilakukan melalui pengamatan yang terfokus pada rangkaian peristiwa dalam rentang tertentu terhadap hubungan yang terkait antarperistiwa, sehingga dapat dipahami bagaimana perubahan dapat terjadi. Oleh karena yang dikaji dalam ilmu arkeologi adalah budaya materialnya, maka dalam artikel ini akan fokus mengkaji pada aspek benda hasil karya 
masyarakat Dayak Ngaju, yaitu bangunan sandung.

Oleh karena itu, untuk dapat menjawab permasalahan di atas maka artikel ini bersifat deskriptif eksplanatif, dengan penalaran induktif (Singarimbun dan Effendi 1989: 3-5). Data artefaktual yang dikumpulkan selama survei diperoleh dengan metode observasi (pengamatan). Pengamatan disertai dengan pencatatan (Bachtiar 1997: 108-128) dilakukan terhadap bahan, bentuk, motif hias, dan letak bangunan sandung yang ada di desa, baik sandung yang berusia muda maupun yang tua. Dari hasil pengamatan tersebut diharapkan dapat memberi gambaran terjadinya perubahan dalam pembangunan sandung. Selain itu, dilakukan juga wawancara kepada masyarakat sekitar sandung. Menurut Koentjaraningrat (1997: 130), wawancara berdasarkan sifatnya ada dua macam, yaitu 1) wawancara untuk mendapatkan keterangan dan data dari individu tertentu untuk keperluan informasi, dan 2) wawancara untuk mendapatkan keterangan tentang diri pribadi, pendirian atau pandangan dari individu yang diwawancarai untuk keperluan komparatif. Jenis wawancara yang dilakukan adalah jenis yang pertama, dengan memilih orang yang mengetahui tentang pendirian sandung yang disebut sebagai informan. Selanjutnya, data yang sudah dikumpulkan akan dianalisis, kemudian dilakukan tahapan sintesis. Studi pustaka dilakukan untuk mendapatkan informasi dan data pendukung lainnya yang membantu dalam proses interpretasi untuk menjawab permasalahan.

\section{HASIL DAN PEMBAHASAN}

\section{Kepercayaan Masyarakat Ngaju}

Dari kegiatan Misionaris yang dimulai pada 1849 di Kuala Kapuas, dapat diketahui informasi tentang kepercayaan Ngaju yang mengenal kosmologis dan dewa-dewa yang menguasai tempat-tempat tertentu (Baier 2007: 566). Kepercayaan primitif ada tiga macam tingkatan, yaitu animisme, dinamisme, dan kepercayaan pada makhluk tertinggi (supreme being) (Schärer
1963: 3-5). Tampaknya, kepercayaan masyarakat Ngaju berada pada tingkatan yang ketiga, yaitu percaya pada supreme being/deity. Hal tersebut dapat diketahui dari sumber tertulis dalam nyanyian suci masyarakat Dayak (Schärer 1963: 8-10). Terdapat dua dewa tertinggi yang dikenal oleh masyarakat Ngaju, yaitu dewa dari dunia atas dan dewa dari dunia bawah. Penguasa dunia atas pada awalnya disebut sebagai Tingang (burung enggang) dan Raja Tontong Matanandau, Kanorohan Tambing Kabantenan Bulan (pangeran matahari dan raja bulan). Selanjutnya, muncul nama asing dari penguasa tertinggi tersebut, yaitu Mahatara, yang di daerah pedalaman juga disebut sebagai Hatara. Sebuah penyebutan yang mirip dengan Dewa Siva dalam etimologi agama Hindu, yaitu Batara Guru (Schärer 1963: 13). Selanjutnya, penguasa dunia bawah (air), dikenal dengan dua nama yang berbeda, yaitu Tambon (naga) dan Bawin Jata Balawang Bulau, yang selanjutnya lebih sering disebut sebagai Jata. Kedua dewa, yaitu dewa dunia atas dan dunia bawah juga melambangkan laki-laki dan perempuan (Schärer 1963: 12-15). Burung enggang dan naga sebagai simbol dunia atas dan dunia bawah digambarkan dalam berbagai benda yang dimiliki masyarakat Dayak, yang terkait dengan upacara daur hidup dan daur kematian. Salah satunya direpresentasikan pada batang garing atau pohon kehidupan, yang diyakini sebagai filosofi dasar kehidupan masyarakat Dayak Ngaju (Sangalang dkk. 2011: 120-123). Simbol ini juga digunakan pada upacara tiwah, yaitu upacara kematian untuk menghantarkan arwah menuju Lewu Tatau dengan penguburan yang kedua (sekunder) (Kusmartono 2009: 208). Penggambaran simbol penguasa dunia atas dan bawah tersebut sangat bervariasi dan distilir antara lain dengan bentuk suluran, motif geometris seperti garis melingkar, dan huruf $\mathrm{S}$ (Sellato 1989: 33-48).

Sejak pengaruh Islam berkembang sampai sekarang, dewa pencipta (Hatara/Mahatara) berubah menjadi Hatalla/Mahatalla. Dikenal juga tokoh Kaloe, seorang wanita yang digambarkan menyeramkan sebagai penguasa permukaan bumi dan yang ada di bawahnya, yang kemudian digantikan oleh Jata, Dewi Sungai. Tampaknya, 
persembahan kepada Jata sudah terpengaruh Islam, yaitu tanpa menggunakan daging babi tetapi dengan daging kambing (Baier 2007: 566).

Sejak tahun 1936 hingga 1960, Ngaju mengenal dua dewa utama, yaitu Hatalla, yang menguasai langit, dan Jata yang menguasai air dan dunia bawah. Selain itu, terdapat juga dewa lain yang mengawasi berbagai aspek kehidupan seperti kesehatan, kesejahteraan, dan kenyamanan, yang dikenal dengan nama Sahor, Bapa Sangunung, dan Indu sangumang. Temlon Telon adalah dewa yang mengawasi roh si mati di alam akhirat, kedudukannya lebih tinggi dari Mahatalla. Pada era kolonial juga dikenal Pataho sebagai dewa perintis dan penjaga desa. Pataho juga dianggap sebagai dewa perang dan pertahanan, pada masa masyarakat melakukan kegiatan mengayau (head hunting) (Baier 2007: 566).

Pada masa pemerintahan Belanda, agama baru diperkenalkan, aktivitas mengayau, pengorbanan budak, dan penyiksaan binatang yang dilakukan saat upacara penguburan dilarang. Banyak masyarakat Dayak yang memeluk agama baru, yaitu Kristen. Pada masa pendudukan Jepang, kepercayaan asli masyarakat Dayak diberi keleluasaan hingga masa kemerdekaan, dan muncullah nama bagi kepercayaan lama masyarakat Ngaju, yaitu Hindu Kaharingan (Baier 2007: 267).

Dari uraian tersebut, dapat dilihat bahwa masyarakat Ngaju adalah sebuah komunitas yang sangat terbuka dengan perubahan, sehingga dalam hal kepercayaan sangat dinamis. Oleh karena itu, dalam proses interaksi dengan pengaruh kepercayan dari luar, perubahan sangat mudah terjadi. Banyak masyarakat yang berganti kepercayaan dari yang lama ke yang baru. Agama Islam mulai masuk sejak berdirinya Kerajaan Banjar yang berpusat di Banjarmasin. Kerajaan Banjar memiliki wilayah kekuasaan yang sangat luas, termasuk wilayah DAS Kahayan. Agama Kristen dibawa oleh kaum Misionaris yang berkembang pada pada masa kolonial Belanda.

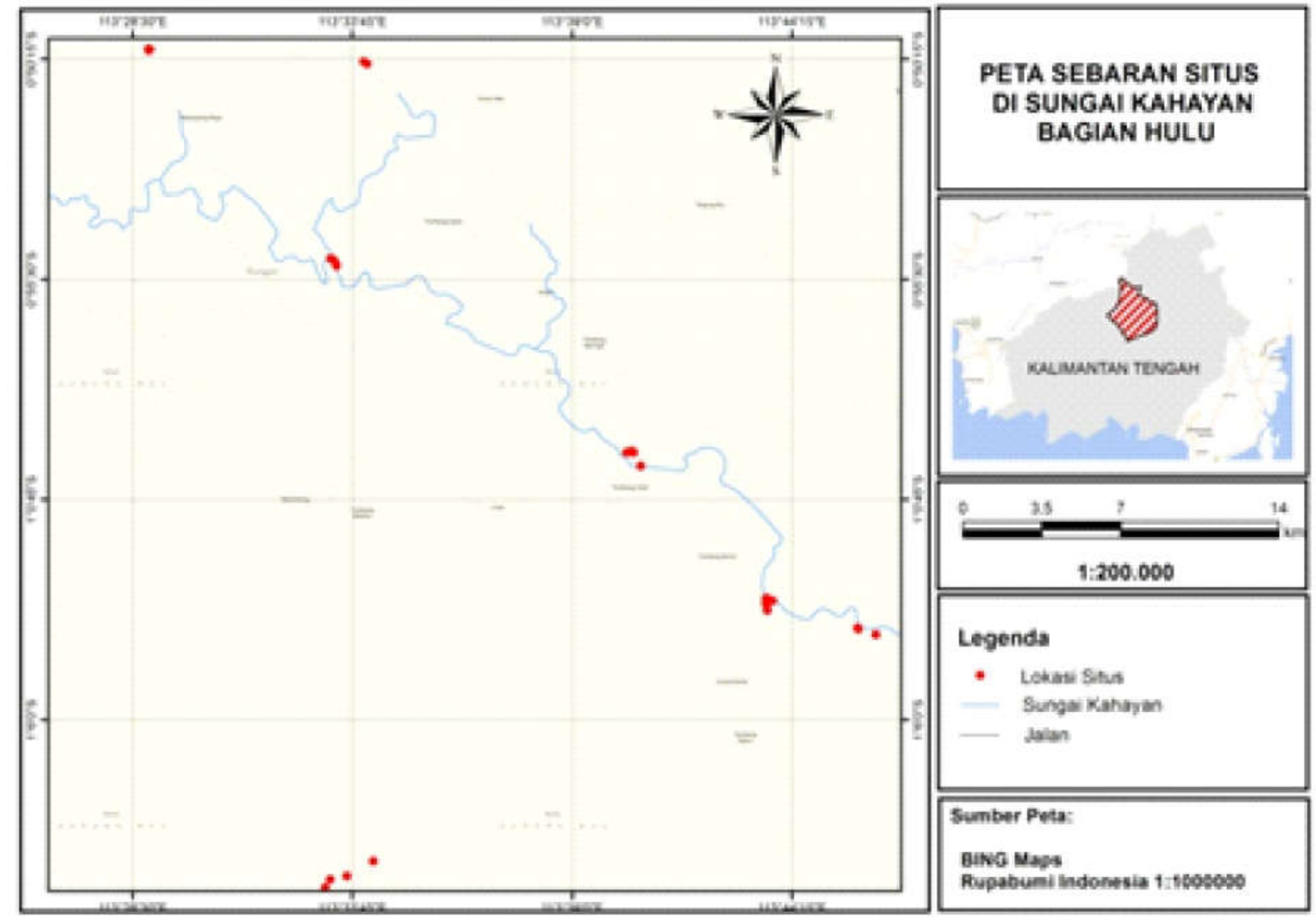

sumber: Balar Banjarmasin

Gambar 1. Lokasi situs dengan temuan sandung di sepanjang DAS Kahayan bagian Hulu (Peta dibuat oleh Ulce Oktrivia, Balar Banjarmasin). 
Meskipun demikian, masih banyak penganut agama asli hingga saat ini di sepanjang DAS Kahayan. Kepercayaan tersebut mempengaruhi kegiatan yang berkaitan dengan daur kematian, yaitu dalam aktivitas penguburan sekunder dengan menggunakan bangunan sandung.

\section{Bangunan Sandung di Hulu DAS Kahayan}

Sandung adalah bangunan kubur sekunder masyarakat Dayak Ngaju yang berbentuk rumah panggung kecil, yang terdiri atas tiang dan tempat tulang di atasnya. Jumlah tiang sandung beragam, yaitu satu, dua, empat, dan enam. Bentuk rumah yang diletakkan di ujung tiang digunakan sebagai tempat untuk menyimpan tulang juga beragam, bentuk dan ukurannya bergantung pada jumlah tiang penyangganya. Demikian juga dengan hiasan baik pada rumah dan tiangnya juga beragam. Sandung yang digunakan oleh masyarakat Dayak Ngaju ini sarat dengan simbol, terutama berkaitan dengan status sosial tokoh yang dimakamkan pada waktu masih hidup, dan cara kematiannya. Bangunan sandung yang akan diuraikan di bawah ini berasal dari hasil survei yang dilakukan Balai Arkeologi Banjarmasin pada 2013 (Sunarningsih 2013: 7-68). Pada penelitian tersebut survei arkeologi mencakup dua wilayah kabupaten yang berada di sepanjang Sungai Kahayan, yaitu Kabupaten Gunung Mas dan Kabupaten Pulang Pisau. Keduanya merupakan kabupaten yang masih baru, hasil dari pemekaran Kabupaten Kapuas. Kabupaten Gunung Mas berada di hulu Sungai Kapuas, sedangkan sebagian besar wilayah Kabupaten Pulang Pisau berada di hilir sungai. Data yang digunakan adalah sandung yang berada di wilayah Kabupaten Gunung Mas (gambar 1).

Kabupaten Gunung Mas yang beribukota di Kuala Kurun, memiliki wilayah seluas 10.804 km², terbagi dalam 11 Kecamatan, yaitu Kecamatan Manuhing, Kecamatan Manuhing Raya, Kecamatan Rungan, Kecamatan Rungan Hulu, Kecamatan Sepang, Kecamatan Mihing Raya, Kecamatan Kurun, Kecamatan Tewah, Kecamatan Kahayan Hulu Utara, Kecamatan Damang Batu, dan Kecamatan Miri Manasa (Seksi Integrasi Pengolahan dan Diseminasi Statistik 2012: 4-6).
Anak Sungai Kahayan yang melintasi beberapa kecamatan tersebut adalah Sungai Manuhing, Sungai Rungan, Sungai Miri.

Penelitian arkeologi pada 2013 hanya melakukan survei di Kecamatan Kurun, Kecamatan Tewah, Kecamatan Rungan, Kecamatan Rungan Hulu, dan Kecamatan Kahayan Hulu Utara. Masing-masing kecamatan tersebut terdiri atas beberapa desa, dan tidak semua desa telah disurvei, hanya sebagian kecil yang didatangi, terutama desa yang dianggap paling tua (awal) telah dihuni oleh masyarakat Ngaju. Pada masing-masing desa ditemukan berbagai macam bangunan sandung yang mewakili masa yang berbeda.

Pada kenyataannya, tidak semua sandung memiliki angka tahun dan diketahui oleh masyarakat kapan sandung tersebut didirikan. Bahkan ada juga sandung yang sudah tidak diketahui lagi pemiliknya karena sudah sangat lama dan kondisi sandung yang sudah tidak utuh dimakan usia. Oleh karena itu, sandung dari daerah hulu ini akan dibedakan menjadi dua, yaitu sandung dari masa sebelum kemerdekaan (1945) dan sandung dari masa sesudah kemerdekaan. Sandung dari masa sebelum kemerdekaan sendiri sebenarnya memiliki rentang waktu yang cukup lama, yaitu masa kolonial dan bahkan mungkin berasal dari masa sebelumnya (pengaruh Hindu Buddha dan Islam). Akan tetapi, sulit untuk membedakan sandung yang tua tersebut karena tidak adanya informasi yang mendukung, misalnya inskripsi. Masing-masing sandung yang memiliki persamaan dan mewakili masa yang sama akan diuraikan pada tabel 1 dan tabel 2 (lihat lampiran).

Dua buah tabel tersebut memberi gambaran adanya perbedaan dalam pembangunan sandung dari masa ke masa. Meskipun pada artikel ini hanya dibedakan menjadi dua masa, yaitu masa sebelum dan sesudah kemerdekaan, tetapi dengan melihat keragaman bentuk sandung, terutama yang berangka tahun, dapat diketahui bahwa pada masa sebelum kemerdekaan sendiri terdapat perbedaan bentuk, ukuran, bahan, dan motif hias, yang menjadi petunjuk adanya perbedaan masa pembuatan sandung. Demikian juga dengan sandung yang dibuat dari masa 
sesudah kemerdekaan. Perubahan yang mewakili masanya tersebut akan diuraikan lebih detail berikut ini.

\section{Perubahan Sandung di Hulu DAS Kahayan}

\section{Perubahan Sandung dari Masa Sebelum Kemerdekaan}

Di Kabupaten Gunung Mas, tidak semua wilayah desa yang disurvei memiliki sandung dari masa ini. Hal tersebut tidak berarti bahwa hanya di wilayah tertentu saja yang punya, karena kondisi sandung yang sudah berusia ratusan tahun tersebut sudah lapuk dan sudah tidak dapat dijumpai lagi. Tokoh yang ada dalam sandung tersebut ada juga yang sudah dipindahkan ke dalam sandung baru oleh keluarganya. Tulang seorang tokoh yang sudah menempati sandung baru antara lain Tamanggung Raden Bintidan Nyai Balau. Kedua tokoh yang hidup dan meninggal pada sekitar 1800- an tersebut sudah menempati sandung dengan bentuk baru, dan juga dipindahkan ke tempat yang baru, sehingga bentuk sandung lamanya tidak dapat dilihat lagi.

Dari tabel 1 dapat dicermati adanya beberapa perubahan sandung tersebut. Oleh karena banyak sandung dari masa ini tidak dilengkapi dengan angka tahun, maka berdasarkan hasil pengamatan dapat dibedakan menjadi tiga kelompok, yaitu masa sebelum 1900, masa 1900an, dan masa 1930-an. Perubahan sandung dari ketiga kelompok tersebut akan diuraikan dalam tabel 3.

\section{Perubahan Sandung dari Masa Setelah Kemerdekaan}

Jumlah sandung dari masa ini lebih banyak, dengan bentuk dan motif hias yang beragam. Seperti halnya sandung dari masa sebelum kemerdekaan, perubahan sandung pada masa sesudah kemerdekaan juga sangat dinamis. Oleh karena itu, untuk mengetahui perubahannya, sandung akan dibagi menjadi kelompok yang lebih kecil sesuai dengan tahun pembuatan sandung tersebut. Untuk sandung yang tidak berangka tahun, akan dikelompokkan berdasarkan kesamaan bentuk dan ragam hias yang ada pada sandung yang berangka tahun. Perubahan sandung akan diuraikan dalam tabel 4.

Dari hasil uraian dalam tabel 3 dan tabel 4 dapat dilihat perubahan yang terjadi pada pembuatan sandung sebagai kubur sekunder masyarakat Dayak Ngaju. Penempatan sandung yang tertua berada di pemukiman lama atau biasa di sebut kaleka, yang saat ini sebagian sudah ditinggalkan. Kaleka adalah sebuah wilayah yang dimiliki oleh sebuah keluarga (kelompok) karena diwariskan dari nenek moyang, di dalamnya terdapat makam leluhur yang menjaga wilayah tersebut, dan dianggap sebagai tempat yang keramat (Rahu dkk. 2013: 7). Biasanya makam leluhur tersebut berada di dalam sebuah kuta, yaitu satu wilayah di dalam kaleka yang diberi pagar keliling sebagai benteng untuk bertahan dari musuh (terutama saat aktivitas pengayauan masih berlangsung). Aktivitas yang merugikan, misalnya menebang pohon besar, tidak boleh dilakukan di tempat tersebut. Luas kaleka beragam, ada yang memiliki luas 1-2 ha, atau bahkan lebih dari 5 ha (Rahu dkk. 2013: 7). Di dalam kaleka tersebut, kelompok masyarakat Dayak Ngaju menanam berbagai macam tumbuhan guna mencukupi kebutuhan hidupnya.

Di dalam kaleka tersebut masyarakat membangun betang (rumah panjang) sebagai tempat tinggal, yang berisi banyak kepala keluarga (hidup secara komunal). Masyarakat mendirikan sandung bagi keluarganya di depan rumah panjang tempat mereka tinggal. Seiring dengan berjalannya waktu dan perubahan cara hidup (masa kolonial Belanda), tidak lagi menggunakan pola hidup komunal, mereka membangun rumah dengan ukuran yang lebih kecil yang hanya ditinggali oleh sebuah keluarga inti. Cara hidup ini dianggap lebih aman dan lebih sehat, yang digalakkan pada saat kolonial masuk. Dengan berubahnya cara hidup tersebut, maka pendirian sandung juga ikut berubah. Masyarakat mulai mendirikan sandung di halaman rumah masing-masing. Pada awal abad ke-21 (19902000), pandangan masyarakat akan letak ideal sebuah sandung berubah, dan mulai menempatkan bangunan sandung di desa mereka 
Tabel 3. Perubahan sandung dari masa sebelum kemerdekaan

\begin{tabular}{|c|c|c|c|c|}
\hline NO. & MASATAHUN & LETAK & BAHAN/BENTUK & MOTIF HIAS \\
\hline 1 & Sebelum 1900 & $\begin{array}{l}\text { Sandung berada di } \\
\text { pemukiman lama yang } \\
\text { biasa disebut oleh } \\
\text { masyarakat sebagai } \\
\text { kuta (dikelilingi pagar) } \\
\text { dan kaleka. Hanya ada } \\
\text { satu tiang yang saat ini } \\
\text { berada di pemukiman } \\
\text { baru, tepatnya di } \\
\text { seberang Kuta Mapot } \\
\text { (Tumbang Lapan). } \\
\text { Sandung dari masa ini } \\
\text { berada di Kaleka } \\
\text { Madehan, Pajangei, } \\
\text { dan Kuta Mapot. }\end{array}$ & $\begin{array}{l}\text { Kayu ulin dengan diameter } \\
\text { tiang antara 30- } 40 \text { meter. } \\
\text { Kebanyakan hanya tertinggal } \\
\text { tiangnya saja tanpa tempat } \\
\text { menyimpan tulang. }\end{array}$ & $\begin{array}{l}\text { Motif hias sandung dari masa ini } \\
\text { dibuat dengan diukirkan pada tiang } \\
\text { dan wadah tulang. Pada tiang } \\
\text { digoreskan tangga arwah yang di } \\
\text { buat berjajar sampai tiga buah, } \\
\text { hasil goresan membentuk motif segi } \\
\text { tiga. Selain tangga arwah juga } \\
\text { diukir motif tumpal yang rumit } \\
\text { (disertai hiasan di dalamnya), } \\
\text { suluran dengan bentuk yang bagus. } \\
\text { Pada salah satu tiang juga dijumpai } \\
\text { pola badan binatang melata (naga) } \\
\text { yang digambarkan menjuntai, } \\
\text { dengan bagian ekor berada di } \\
\text { bawah. }\end{array}$ \\
\hline 2 & Masa 1900-an & $\begin{array}{l}\text { Sandung dari masa ini } \\
\text { juga berada di bekas } \\
\text { kaleka, tetapi saat ini } \\
\text { sudah dijadikan } \\
\text { pemukiman baru, yaitu } \\
\text { di Kuala Kurun, dan } \\
\text { berada di pekarangan } \\
\text { ahli warisnya. }\end{array}$ & $\begin{array}{l}\text { Sandung dari masa ini dibuat } \\
\text { dari kayu ulin. Ada tiga } \\
\text { macam bentuk, yaitu sandung } \\
\text { bertiang satu, bertiang dua, } \\
\text { dan bertiang empat. Diameter } \\
\text { tiang antara } 20-30 \mathrm{~cm} \text {. Tinggi } \\
\text { tiang sandung antara } 2 \text { - } 6 \\
\text { meter, yang terpendek adalah } \\
\text { sandung bertiang dua, } \\
\text { s edangkan yang paling tinggi } \\
\text { adalah sandung bertiang satu } \\
\text { dan bertiang empat. Bentuk } \\
\text { rumah tulang pada sandung } \\
\text { bertiang satu dan empat } \\
\text { adalah segi empat (kubus) } \\
\text { dengan atap berbentuk } \\
\text { segitiga dan berundak-undak, } \\
\text { sedangkan sandung bertiang } \\
\text { dua adalah persegi panjang } \\
\text { menyerupai kapal dengan } \\
\text { atap melengkung tanpa } \\
\text { undakan. }\end{array}$ & $\begin{array}{l}\text { Motif hias sandung kelompok ini } \\
\text { dibuat dengan cara diukir. Pada } \\
\text { bagian tiang terdapat motif kedok } \\
\text { dengan lidah yang terjulur ke luar, } \\
\text { dan tangga arwah satu baris, } \\
\text { sedangkan pada dinding tempat } \\
\text { tulang antara lain terdiri atas motif } \\
\text { flora suluran, ikan, stiliran naga, } \\
\text { dan manusia. }\end{array}$ \\
\hline 3 & Masa 1930-an & $\begin{array}{l}\text { Sandung dari masa ini } \\
\text { berada di pemukiman } \\
\text { baru, terletak di } \\
\text { pekarangan penduduk. } \\
\text { Hanya saja sandung } \\
\text { yang berada di Upun } \\
\text { Batu berada di } \\
\text { pemukiman baru. }\end{array}$ & $\begin{array}{l}\text { Ada dua buah sandung dari } \\
\text { kayu ulin, satu buah sandung } \\
\text { masih lengkap, bertiang } \\
\text { empat dan bentuk rumah } \\
\text { tulangnya segi empat. Satu } \\
\text { sandung lagi tinggal bentuk } \\
\text { rumah tulangnya saja yang } \\
\text { segi empat, tiangnya sudah } \\
\text { tidak ada, dan diletakkan di } \\
\text { atas pondasi beton yang } \\
\text { berundak. Pada sandung } \\
\text { tanpa tiang ini terdapat angka } \\
\text { tahun yangjelas, yaitu } 1936 \text {. }\end{array}$ & $\begin{array}{l}\text { Kedua sandung diberi hiasan } \\
\text { dengan teknik ukir dan dipercantik } \\
\text { dengan cat berwarna. Pada bagian } \\
\text { tiang diberi motif ukiran tumpal dan } \\
\text { tangga arwah satu baris. Bagian } \\
\text { wadah tulang diberi ukiran dengan } \\
\text { motif yang raya. Di bagian dinding } \\
\text { rumah diukir dengan motif flora } \\
\text { suluran (ukel gelung), manusia dan } \\
\text { burung. Pada bagian puncak atap } \\
\text { diberi ukiran motif flora suluran dan } \\
\text { burung, stiliran naga (membentuk } \\
\text { huruf S) ditempatkan di ujung tiang } \\
\text { segi tiga yang melintang ke arah } \\
\text { depan dan belakangatap. }\end{array}$ \\
\hline
\end{tabular}


Tabel 4. Perubahan sandung dari masa setelah kemerdekaan

\begin{tabular}{|c|c|c|c|c|}
\hline NO. & MASA/TAHUN & LETAK & BAHAN/BENTUK & MOTIF HIAS \\
\hline 1. & $\begin{array}{l}\text { Mas a } 1950 \text { s.d. } \\
1970-a n\end{array}$ & $\begin{array}{l}\text { Letak sandung dari } \\
\text { mas a in i berada di } \\
\text { halaman keluarga } \\
\text { masing masing, } \\
\text { biasanya berada di } \\
\text { depan rumah, dengan } \\
\text { a rah hadap sandung } \\
\text { ke sungai. }\end{array}$ & $\begin{array}{l}\text { Bahan yang digunakan be rupa } \\
\text { kayu ulin, te ta pi diamete mya } \\
\text { kecil (sek itar } 10 \mathrm{~cm} \text { ) dan } \\
\text { ketinggiannya antara } 1-2 \\
\text { meter. Pada kelompok in i } \\
\text { muncul bentuk sandung } \\
\text { bertiang dua yang jarak antara } \\
\text { dua tiangnya pendek, } \\
\text { sehing ga bentuk rumah } \\
\text { tulangnya tidak persegi } \\
\text { panjang tetapi persegi empat, } \\
\text { mirip dengan rumah tulang } \\
\text { pada sandung bertiang empat. } \\
\text { A kan tetapi, ada juga sandung } \\
\text { bertiang satu yang bentuk } \\
\text { rumah tulangnya segi empat } \\
\text { memanjang ke atas, lengkap } \\
\text { dengan tutup. }\end{array}$ & $\begin{array}{l}\text { Motif hias pada pada kelompok } \\
\text { sandung ini mas ih menggunakan } \\
\text { teknik ukir, dengan tambahan cat } \\
\text { be rwarna. Ukiran dibuat teliti dan } \\
\text { de til mirip dengan sandung dari } \\
\text { era } 1930 \text {-an, hany a kurang raya. } \\
\text { Motif hias yang diukir pada bagian } \\
\text { tiang adalah hias tum pal dan } \\
\text { tangga arwah, ada juga motif } \\
\text { kedok dengan lidah yang } \\
\text { menjulurkeluar. Motif ukiran juga } \\
\text { digores kan pada rumah tulang, } \\
\text { un tuk dinding rumah antara lain } \\
\text { be rupa motif flora suluran, } \\
\text { manusia, stiliran naga. Pada } \\
\text { bagian atap juga diberi ukiran } \\
\text { motif sulu ran dan burung. }\end{array}$ \\
\hline 2 & $\begin{array}{l}\text { Masa } 1980 \text { s.d. } \\
2000 \text {-an }\end{array}$ & $\begin{array}{l}\text { Letak sandung dari } \\
\text { masa in i selain ada di } \\
\text { halaman pemilik } \\
\text { sandung juga berada } \\
\text { di kompleks kuburan, } \\
\text { baik kompleks kubur } \\
\text { sandung maupun } \\
\text { kompleks kubur } \\
\text { muslim (yang ada di } \\
\text { Tewah). }\end{array}$ & $\begin{array}{l}\text { Bahan yang digunakan be rupa } \\
\text { kayu ulin dan beton. Muncul } \\
\text { bentuk sandung baru, yaitu } \\
\text { tanpa tiang yang mayoritas } \\
\text { terbuat dari bahan beton } \\
\text { (campuran semen dan pasir). } \\
\text { Untuk bentuk sandung yang } \\
\text { bertiang, baik satu, dua, dan } \\
\text { empat masih dibuat dari kayu } \\
\text { ulin, tetapi diameter dan tinggi } \\
\text { tiangnya semakin kecil dan } \\
\text { pendek. }\end{array}$ & $\begin{array}{l}\text { Motif hias yang muncul pada } \\
\text { masa ini masih berupa ukiran } \\
\text { (yang diberi cat warna) dan } \\
\text { lukisan dengan menggunakan cat } \\
\text { warna. Kedua jenis te knik } \\
\text { pembuatan hiasan tersebut ada di } \\
\text { sandung kayu dan beton. Pada } \\
\text { sandung kayu ukiran yang dibuat } \\
\text { masih lebih bagus dibandingkan } \\
\text { dengan uiran pada sandung } \\
\text { beton. Demikian juga dengan } \\
\text { lukisannya, di media kayu mas ih } \\
\text { lebih bagus daripada media beton. }\end{array}$ \\
\hline 3 & $\begin{array}{l}\text { Mas a 2000-an } \\
\text { sampai } \\
\text { sekarang }\end{array}$ & $\begin{array}{l}\text { Sandung yang berada } \\
\text { di halaman penduduk } \\
\text { hampir semuanya } \\
\text { menghadap ke sungai } \\
\text { kecuali sandung di } \\
\text { Desa Tajungan. }\end{array}$ & $\begin{array}{l}\text { Sandung berbahan beton juga } \\
\text { dibuat dengan bentuk bertiang } \\
\text { satu dan empat, kebanyakan } \\
\text { a dalah bertiang satu, hanya } \\
\text { a da satu buah sandung beton } \\
\text { bertiang empat di Desa } \\
\text { Tewah, y ang dibuat pada } 2013 \\
\text { (terbaru) }\end{array}$ & 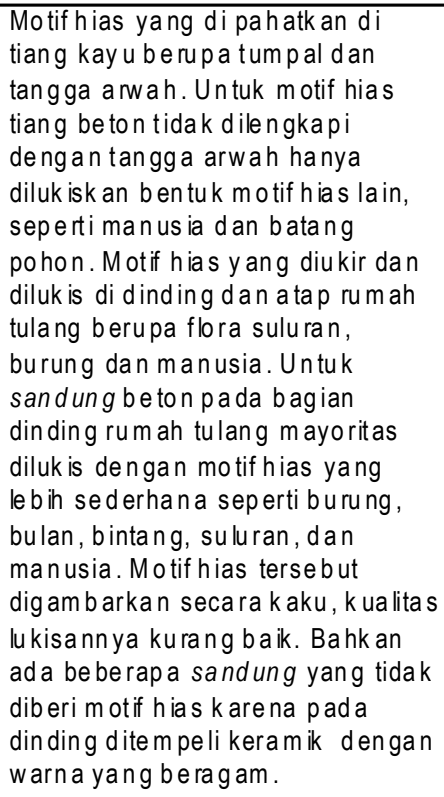 \\
\hline
\end{tabular}


dalam satu kompleks kuburan. Alasan terjadinya perubahan tersebut tampaknya didasarkan pada keterbatasan tempat yang mereka miliki dan juga hilangnya tanah tempat sandung leluhur mereka karena tergerus oleh aliran sungai. Pada akhirnya mereka memilih untuk menempatkan sandung pada sebuah areal khusus. Meskipun letak pendirian sandung mengalami perubahan, tetapi arah hadap dari sandung tersebut tetap, yaitu ke arah sungai. Sungai memang diyakini sebagai jalur perjalanan arwah dengan menggunakan perahu menuju Lewu Tatau (alam arwah).

Bahan pembuat sandung bisa dikatakan mengalami penurunan dari segi kualitas. Sandung tua menggunakan kayu ulin yang diameter tiangnya besar dan sangat tinggi, sedangkan sandung yang muda menggunakan kayu ulin yang lebih kecil dan pendek (gambar 2 dan 3). Ketersediaan bahan baku kayu sebagai bahan pokok pembuat sandung menjadi sangat sulit diperoleh. Hal tersebut sangat mudah dipahami karena kayu ulin memiliki masa hidup yang sangat lama apalagi untuk dapat mencapai diameter batangnya sekitar 40 centimeter, sehingga jenis kayu ini tidak dijadikan tanaman yang dibudidayakan oleh masyarakat. Keberadaan kayu ulin pada akhirnya semakin berkurang karena tingginya tingkat kebutuhan sebagai bahan

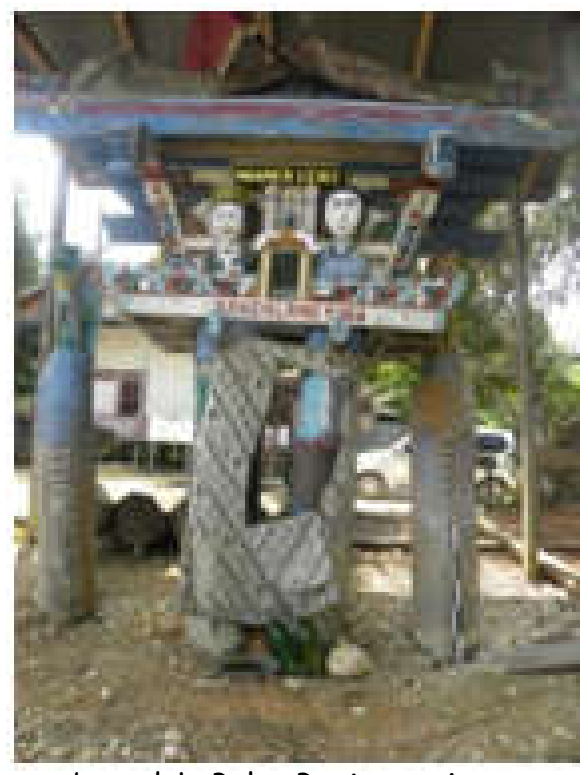

sumber: dok. Balar Banjarmasin

Gambar 2. Sandung bertiang empat (pendek) di Desa Teluk Nyatu. penyusun bangunan. Seiring dengan adanya pelarangan illegal logging dan pembatasan pendistribusian kayu ulin, maka harga kayu jenis ini menjadi sangat mahal dan sulit untuk didapatkan. Masyarakat akhirnya mengubah bahan pembuatan sandung dari kayu ulin menjadi sandung dari beton (campuran pasir dan semen). Selain biayanya lebih murah, sandung dari beton

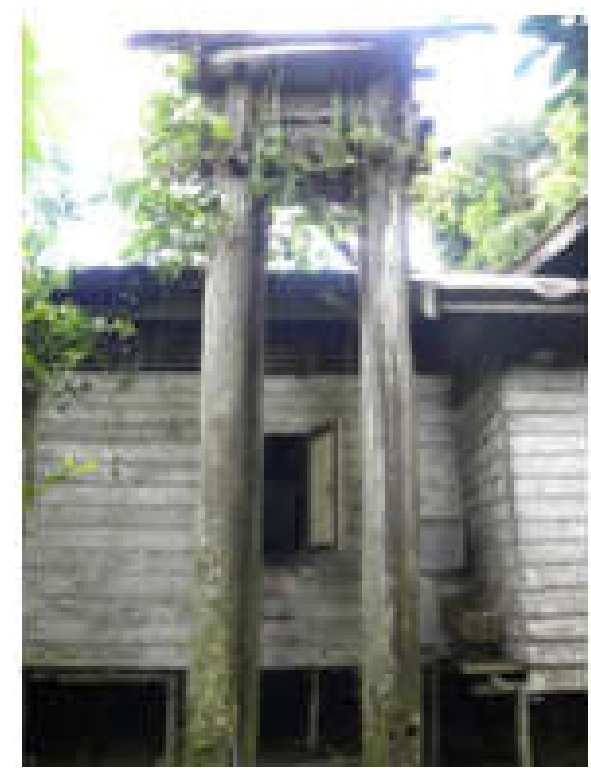

sumber: dok. Balar Banjarmasin

Gambar 3. Sandung bertiang empat (tinggi) di Desa Kuala Kurun.

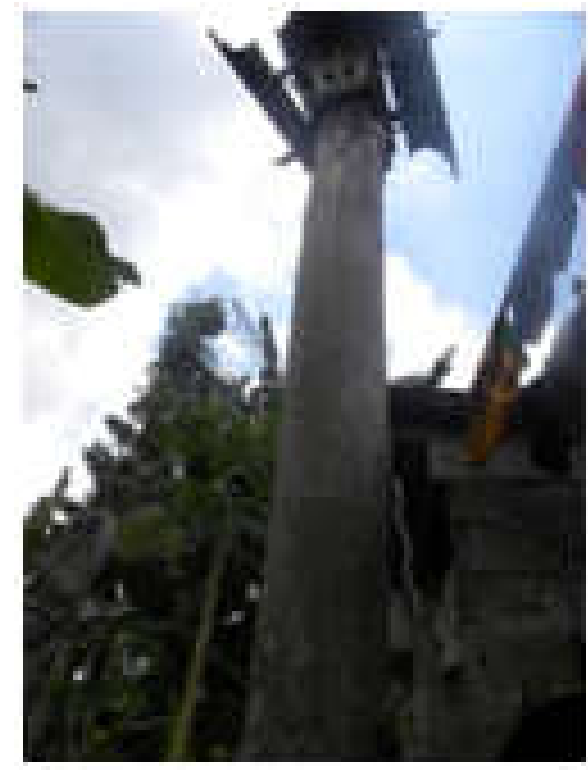

sumber: dok. Balar Banjarmasin

Gambar 4. Sandung bertiang satu dengan bentuk wadah tulang persegi empat mendatar, dari Desa Tewah. 
juga dinilai lebih awet karena tahan terhadap perubahan cuaca, panas dan hujan.

Tujuan dari pembuatan kubur sekunder tersebut sangat jelas, yaitu untuk mengantarkan arwah si mati menuju dunia atas. Adanya tiang sandung dengan pahatan tangga arwah ditujukan agar arwah mudah berjalan menuju dunia atas yang diberi simbol dengan burung enggang atau tingang. Keberadaan burung itu sendiri banyak digambarkan di bagian tertinggi, yaitu di puncak atap sandung. Simbol dunia bawah yang

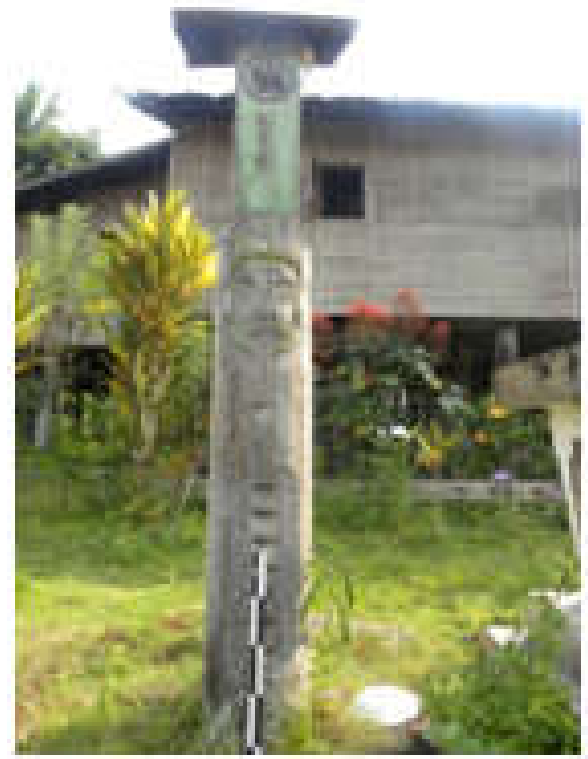

sumber: dok. Balar Banjarmasin

Gambar 5. Sandungbertiang satu dengan bentuk wadah tulang persegi empat lurus ke atas, dari Desa Tumbang Malahoi.

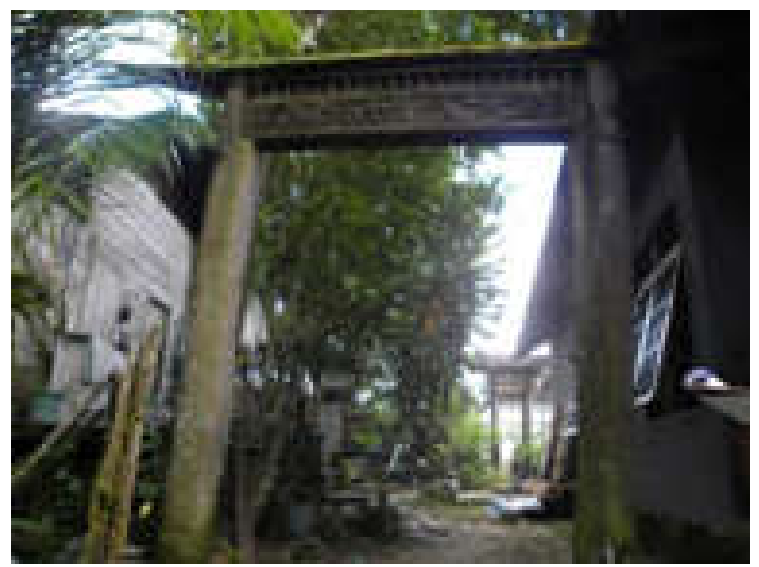

sumber: dok. Balar Banjarmasin

Gambar 6. Sandung bertiang dua dengan bentuk wadah tulang memanjang, dari Desa Kuala Kurun. digambarkan sebagai naga atau tempayan ditempatkan di bagian dinding rumah atau di atap bagian bawah. Kedua simbol penting tersebut terlihat dengan jelas pada bangunan sandung dari tiap masa. Penggambaran simbol tersebut sangat bervariasi, dan bisa dikatakan dari sandung tua ke sandung muda sudah mengalami penurunan dalam segi kualitas penggambarannya. Takikan tangga arwah di tiang sandung bahkan dihilangkan sama sekali. Awalnya yang diukirkan tiga baris dalam sebuah tiang sandung, kemudian berkurang menjadi satu baris, dan akhirnya ditiadakan sama sekali karena ketiadaan tiang penyangga, terutama pada bentuk sandung tanpa tiang dari beton. Selain itu, penggunaan motif hias pada wadah tulang juga mengalami penurunan

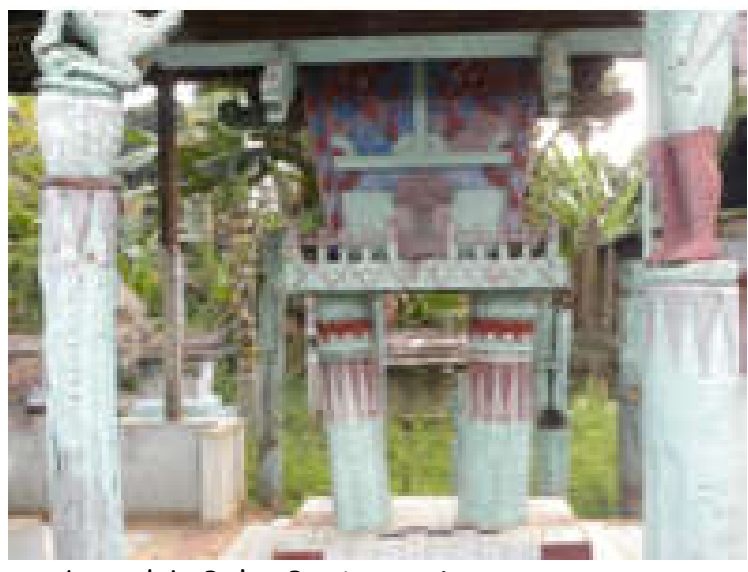

sumber: dok. Balar Banjarmasin

Gambar 7. Sandung bertiang dua dengan bentuk wadah tulang persegi empat mendatar, dari Desa Tumbang Miri.

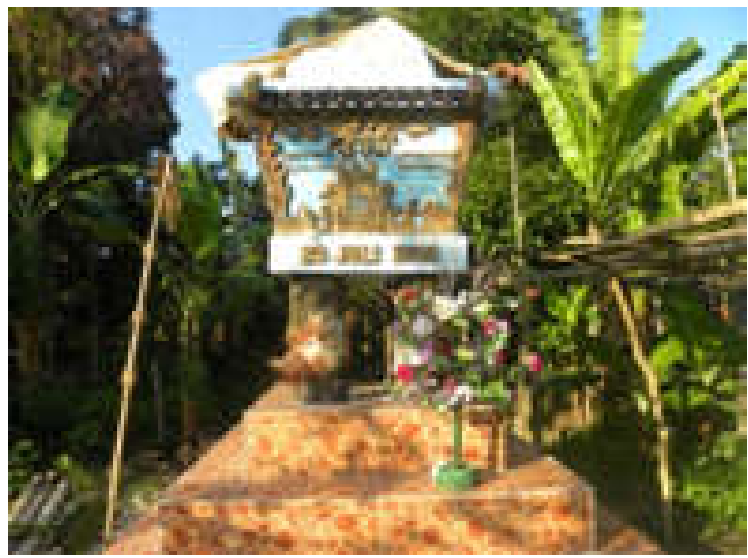

sumber: dok. Balar Banjarmasin

Gambar 8. Sandung beton bertiang empat, dari Desa Tewah. 
(baik dari segi kualitas maupun kuatitasnya), dari penggunaan motif ukiran yang raya pada media kayu ulin, berubah menjadi ukiran yang kaku, baik di media kayu maupun beton. Teknik ukiran yang digunakan pada akhirnya berkurang, digantikan oleh teknik lukisan dengan cat berwarna. Motif hias dengan teknik lukis yang menghiasi dinding sandung, baik dari kayu maupun dari beton kualitasnya jauh berbeda, lukisannya lebih sederhana.

Variasi bentuk juga wajar muncul pada masa yang berbeda. Sandung bertiang satu yang hanya digunakan oleh orang-orang tertentu, yaitu bila si mati tidak mempunyai keturunan atau meninggal secara tidak wajar karena kecelakaan. Sandung ini mempunyai dua bentuk tempat tulang yang berbeda (gambar 4 dan 5), yaitu rumah segiempat dan rumah persegi yang memanjang ke atas (peletakan bagian lebarnya di bawah dan di atas bukan di samping). Demikian juga dengan sandung bertiang dua, bentuk rumah tulangnya juga berbeda, ada dua macam, yang disebabkan karena perbedaan jarak penempatan antara dua buah tiang (gambar 6 dan 7). Penggunaan motif kedok dengan lidah yang menjulur keluar, tetap digunakan pada sandung tertentu, baik yang yang bertiang satu, bertiang dua maupun bertiang empat dari sandung tua dan muda. Akan tetapi, penggambaran kedok tersebut mengalami penurunan dari segi kualitas. Kedok tersebut yang disebut sebagai bukong, hanya digunakan untuk sandung orang-orang tertentu. Bukong adalah penggambaran dari penjaga yang berwajah seram, hidung bengkok, dengan mulut menyerupai ular, dan lidah terjulur (Gill 1967: 82).

Perubahan dalam penggunaan motif hias memang sangat dipengaruhi oleh media dan seniman yang membuatnya. Alasan yang diduga sangat mempengaruhi diabaikannya aspek keindahan dalam pembuatan sandung antara lain adalah sikap dari keluarga si mati. Tidak dapat dipungkiri bahwa sandung hanya ditujukan pada penganut Kaharingan. Meskipun pada saat ini masih banyak ditemui para penganut Kaharingan di desa sepanjang Sungai Kahayan, tetapi jumlahnya masih lebih banyak penganut agama lain, yaitu Kristen. Keluarga si mati yang membuatkan bangunan sandung bagi anggota keluarganya yang masih menganut Kaharingan, tampak sekali pada sandung beton yang dibangun pada 2013 di Desa Tewah (gambar 8). Oleh karena itu, dapat dipahami bahwa nilai kepraktisanlah yang mereka pilih. Selain itu, keberadaan tokoh yang berpengaruh dari kelompok Kaharingan saat ini relatif sudah sangat berkurang dibandingkan dulu. Pada masa lalu banyak tokoh "besar" dengan gelar yang melekat dan disegani, sehingga sandungnya sampai dengan saat ini masih dipelihara dan dihormati oleh masyarakat. Misalnya tokoh Dambung Rupuk, Nyai Balau, Tamanggung Kanyapi, dan Singa Duhung. Bangunan sandung untuk para tokoh tersebut rutin dirawat dan direhab oleh keluarganya. Akan tetapi, dalam kegiatan perawatan tersebut banyak yang mengubah total sandung para tokoh tersebut sesuai dengan kehendak keluarganya, ada yang masih mempertahankan bahan pembuat sandung dari kayu ulin, tetapi ada juga yang mengubahnya menjadi sandung beton. Apalagi sandung dari masyarakat biasa, akan sangat logis bila dibuat sesuai dengan kemampuan keluarganya, pilihannya adalah segi pembiayaan yang lebih terjangkau dan bahan baku yang lebih awet.

\section{PENUTUP}

Sandung sebagai bangunan kubur sekunder masih didirikan oleh masyarakat Ngaju hingga saat ini. Meskipun jumlah masyarakat penganut Kaharingan sudah semakin berkurang, dan pihak keluarga yang ditinggalkan sudah berubah keyakinan, mereka tetap menjalankan ritual sesuai dengan keyakinan si mati. Dapat diketahui bahwa beberapa unsur yang berubah dalam pendirian sebuah sandung adalah lokasi sandung didirikan, bentuk, bahan, motif hias (jenis dan teknik pengerjaannya), dan konsep. Lokasi pendirian sandung yang biasanya berada di halaman milik keluarga mulai berubah dengan dipindahkan ke kompleks makam desa. Demikian juga dengan bentuk dan bahan yang saling berkaitan, dari sandung kayu bertiang menjadi sandung beton tanpa tiang. Perubahan tersebut akhirnya berpengaruh juga pada pemakaian motif hias yang dulunya diukirkan dikayu dengan 
bentuk yang sangat bervariasi menjadi hiasan tempel di beton dan hiasan dengan cat berwarna dengan motif yang lebih sederhana.

Perubahan tersebut dipengaruhi oleh beberapa hal, yaitu perubahan tata cara hidup (bermukim), ketersediaan bahan baku di lingkungan sekitar, perubahan cara pandang masyarakat terhadap keberadaan sandung, perubahan kepercayaan keluarga si mati yang menyediakan bahan pembuatan sandung, dan perubahan tren. Perubahan tersebut, tampaknya sebagian disebabkan adanya pengaruh dari luar, yang sangat mempengaruhi kepercayaan dan cara hidup, terutama dimulai saat kolonial berkuasa. Masyarakat pada awalnya hidup dengan cara komunal kemudian menjadi individual, dilarangnya kegiatan mengayau dan aktivitas perbudakan, serta perubahan kepercayaan pada sebagian masyarakat. Ketika kemerdekaan sudah diperoleh, kebijakan yang diterapkan pada masyarakat, misalnya pada struktur birokrasi yang dijalankan pada akhirnya mengubah kehidupan yang tadinya bersifat tradisional menjadi lebih modern. Peran tokoh masyarakat yang masih menjunjung tinggi kepercayaan leluhur semakin terkikis dengan terjadinya perubahan yang mengatasnamakan pembangunan. Tuntutan yang dihadapi oleh masyarakat menjadi lebih kompleks, masuknya industri dan pertambangan juga sangat mempengaruhi cara hidup dan berpikir masyarakat. Pembabatan hutan dan eksploitasi kayu ulin sangat memberi efek pada ketidakmampuan masyarakat untuk membelinya. Di lain pihak, semen dan pasir lebih mudah diperoleh dan lebih murah. Perubahan dalam cara hidup dan lingkungan tersebut pada akhirnya berpengaruh terhadap konsep masyarakat dalam memperlakukan kubur sandung.

Meskipun demikian, masih ada hal yang dipertahankan, yaitu arah hadap sandung yang mayoritas masih menghadap ke aliran sungai terdekat. Selain itu juga tetap dipertahankannya hiasan burung yang diletakkan di puncak atap sandung. Cara penguburan sekunder ini tentunya masih akan tetap bertahan selama masyarakat Ngaju pemeluk kepercayaan asli masih ada.

\section{DAFTAR PUSTAKA}

Alam, Bachtiar. 1998. "Globalisasi dan Perubahan Budaya: Perspektif Teori Kebudayaan". Jurnal Antropologi Indonesia 54: 1-11. Diunduh 16 Maret 2015. (Journal.ui.ac.id/ index-php/jai/article/View Article/3325).

Bachtiar, Harsja W. 1997. "Pengamatan sebagai Suatu Metode Penelitian". HIm. 108-128, dalam Metode-metode Penelitan Masyarakat, editor oleh Koentjaraningrat. Jakarta: Gramedia Pustaka Utama.

Baier, Martin. 2007. "The Development of the Hindu Kaharingan Religion: a New Dayak Religion in Central Kalimantan". Anthropos Bd. 102. H.2: 566-570.

Gill, Sarah. 1967. "Style Demonic Image in Dayak Mask". Journal of the Malaysian Branch of the Royal Asiatic Society 4(1): 78-92.
Harris, Marvin. 1997. Culture, People, Nature: an Introduction to General Anthropology. New York: Addison-Wesley Educational Publisher Inc.

Hartatik. 2000. "Survei Arkeologi di Kotawaringin Timur, Provinsi Kalimantan Tengah". Laporan Penelitian Arkeologi. Balai Arkeologi Banjarmasin.

Koentjaraningrat. 2007. "Metode Wawancara". HIm. 129-157 dalam Metode-metode Penelitian Masyarakat, diedit oleh Koentjaraningrat. Jakarta: Gramedia Pustaka Utama. 2009. Pengantar IImu Antropologi. Jakarta: Rineka Cipta.

Kusmartono, Vida Pervaya R. 2009. "Tiwah: the Art of Death in Southern Kalimantan". Naditira Widya 1 (2): 206-213. 
Rahu, Anggie Abhan, Kliwon Hidayat, Mahrus Ariyadi, dan Luchman Hakim. 2013. "Ethnology of Kaleka: Dayak's Agroforestry in Kapuas, Central Kalimantan Tengah". Research Journal of Agriculture and Forestry Sciences 1 (8): 5-12.

Rampai, Kiwok D. 1985. "Bangunan Makam Orang Ngaju di Kalimantan Tengah Suatu Studi Etnoarkeologi". HIm. 883-898 dalam Pertemuan IImiah Arkeologi III Ciloto 2328 Mei 1983. Jakarta: Pusat Penelitian Arkeologi Nasional.

Sangalang, Indrabakti, Endang Titi Sunarti Darjosanjoto, dan Muhammad Faqih. 2011. "Understanding Space Based on the Symbol of Batang Garing on Dayak Ngaju House". HIm. 118-126 dalam Local Wisdom in Global Era Enhancing the Locality in Architecture Housing and Urban Environment,. Yogyakarta: Duta Wacana University Press.

Schärer, Hans. 1963. Ngaju Religion the Conception of God Among a South Borneo People. Koninklijk Instituut voor Taal-, Land-, en Volkenkunde. The Hague: Martinus Nijhoff.

Seksi Integrasi Pengolahan dan Diseminasi Statistik. 2012. Gunung Mas dalam Angka.
Gunung Mas: BAPPEDA dan Badan Pusat Statistik Kabupaten Gunung Mas.

Sellato, Bernard. 1989. Naga dan Burung Enggang, Kalimantan, Sarawak, Sabah, Brunei. Malaysia: Elf Aquatine.

Singarimbun, Masri dan Sofian Effendi (ed.). 1989. Metode Penelitian Survai. Jakarta: LP3ES.

Sulistyanto, Bambang. 2004. "Upacara Tiwah Masyarakat Dayak Ngaju di Pendahara". Berita Penelitian Arkeologi 13. Banjarbaru: Balai Arkeologi Banjarmasin.

Sunarningsih. 2013. "Penelitian arkeologi DAS Kahayan, Kalimantan Tengah". Laporan Penelitian Arkeologi. Balai Arkeologi Banjarmasin.

Tim Penyusun Kamus Pusat Pembinaan dan Pengembangan Bahasa. 1995. HIm. 234 dalam Kamus Besar Bahasa Indonesia. Jakarta: Balai Pustaka.

Turner, Victor. 1967. The Forest of Symbol: Aspects of Ndembu Ritual. Ithaca: Cornell University Press.

Winarto, Yunita T. 1999. "Pendekatan Prosesual: Menjawab Tantangan dalam Mengkaji Dinamika Budaya". Jurnal Antropologi Indonesia 60: 24-34. Diunduh 16 Maret 2015. (Journal.ui.ac.id/index-php/jai/ article/View Article/3354). 


\section{LAMPIRAN.}

Tabel 1. Sandung di hulu DAS Kahayan sebelum masa kemerdekaan

\begin{tabular}{|c|c|c|c|c|c|}
\hline \multirow[t]{2}{*}{ No } & \multirow{2}{*}{$\begin{array}{c}\text { Kecamatan/ } \\
\text { Desa }\end{array}$} & \multicolumn{3}{|c|}{ Bentuk dan jumlah sandung } & \multirow[t]{2}{*}{ Letak, bah an dan motif hias } \\
\hline & & Bertiang satu & Bertiang dua & Bertiang empat & \\
\hline 1 & $\begin{array}{l}\text { Kec. Kuala } \\
\text { Kurun, } \\
\text { Kelurahan } \\
\text { Kuala Kurun }\end{array}$ & & $\begin{array}{l}\text { Ada tiga buah, } \\
\text { dengan bentuk tem pat } \\
\text { tulang persegi empat } \\
\text { panjang dan bertutup } \\
\text { dengan bentukyang } \\
\text { meruncing pada } \\
\text { kedua ujungnya } \\
\text { (menyerup ai bentuk } \\
\text { kapal/jukung). Tinggi } \\
\text { sandung sekitar } 3 \\
\text { meter }\end{array}$ & $\begin{array}{l}\text { Ada tiga buah, dengan } \\
\text { bentuk te mpat tulang } \\
\text { persegi empat lengkap } \\
\text { dengan tutupnya yang } \\
\text { dibentuk seperti atap } \\
\text { rumah (se gi tiga). Tinggi } \\
\text { sandung antara } 4-6 \\
\text { meter. Ada satu buah } \\
\text { sandung yang sangat } \\
\text { tinggi melebihi atap } \\
\text { rumah panggung di } \\
\text { depannya. }\end{array}$ & $\begin{array}{l}\text { Ke enam sandung ini berada di se kitar } \\
\text { perumahan yang berjajar di Jalan Sang kurun, } \\
\text { Kuala Kurun. Semua sandung men ghadap ke } \\
\text { sungai yang dibatasi oleh jalan ka mpung dan } \\
\text { deretan rumah. Bahan pembuat sandung ini } \\
\text { a dalah kayu ulin yang diberi ukiran baik pada } \\
\text { tiang maupun pada wada h tulang. Untuk } \\
\text { sandung bertiang dua, motif hias ukirannya } \\
\text { berupa takikan tang ga arwah dan kedok dengan } \\
\text { lidah yang te julur, sedangkan pada bagian } \\
\text { penyimpan tulang diberi ukiran den gan motif } \\
\text { hias yang lebih raya, yaitu ikan dan motif flora } \\
\text { suluran. Untuk sandung bertiang empat, } \\
\text { tiangnya dilengkapi dengan takikan tangga } \\
\text { arwah, se dangkan bagian penyimpan tulang } \\
\text { dihiasi dengan motif flora suluran, sepasang } \\
\text { manusia, dan kepala naga. Baik tiang maupun } \\
\text { tempat tulang tidak diberi wama cat, tetapi } \\
\text { tampak bahwa motif hias yang diukirkan di } \\
\text { keenam sandung ini detil dan dikerjakan dengan } \\
\text { bagus. }\end{array}$ \\
\hline 2 & $\begin{array}{l}\text { Kecamatan } \\
\text { Tewah, } \\
\text { Kelurahan } \\
\text { Tewah }\end{array}$ & $\begin{array}{l}\text { Sandung bertiang satu } \\
\text { dengan bentuk tempat } \\
\text { tulang persegi empat } \\
\text { yang uku rannya } \\
\text { disesuaikan dengan } \\
\text { diameter tiang, yang } \\
\text { untuk uku ran kayu ulin } \\
\text { te rmasuk besar, yaitu } \\
\text { sekitar } 30 \mathrm{~cm} \text {. Tinggi } \\
\text { tiang sekitar } 6 \text { meter }\end{array}$ & & & $\begin{array}{l}\text { Sandung ini terbuat dari kayu ulin dengan } \\
\text { diameter } 30 \mathrm{~cm} \text {, dilengkapi dengan hia san } \\
\text { tumpal dan takkan tangga arwah pada tiang. } \\
\text { Motif hias pa da tempat tulang berupa ukiran } \\
\text { flora sulu ran, sedan gkan hia san pa da bagian } \\
\text { atap sudah tidak nampak lagi karena kondisi } \\
\text { atap yang sudah tidak utuh lagi. Hiasan pada } \\
\text { sand ung tidak diberi cat berwama. Sandung ini } \\
\text { berada tepat di bibir sungai Kahayan, dan } \\
\text { menghadap ke sungai. Sandung ini milik } \\
\text { Temenang. Tempat ini pada masa lalu } \\
\text { merupakan seb uah pemukiman lama yang } \\
\text { dipimp in oleh tokoh wanita, Nyai Balau, yang } \\
\text { sand ungnya sudah dipindahkan ke kompleks } \\
\text { pemakaman de sa pada } 1996 \text { dengan upacara } \\
\text { tiwah masal. }\end{array}$ \\
\hline 3. & $\begin{array}{l}\text { Kecamatan } \\
\text { Tewah, } \\
\text { Kelurahan } \\
\text { Tumbang } \\
\text { Pajangei }\end{array}$ & $\begin{array}{l}\text { Sandung bertiang satu } \\
\text { berjumlah satu buah, } \\
\text { dengan kondisi yang } \\
\text { sudah tidakutuh. } \\
\text { Bagian rumah tulang } \\
\text { sudah tidakada }\end{array}$ & $\begin{array}{l}\text { Sand ung bertiang dua } \\
\text { ini jug a su dah tidak } \\
\text { utuh lagi, bagian } \\
\text { rumah tem pat tulang } \\
\text { sudah hilang. Jumlah } \\
\text { satu buah sandung. }\end{array}$ & $\begin{array}{l}\text { Sandung bertiang empat } \\
\text { juga sudah tidak utuh, } \\
\text { bagian rumah tulang di } \\
\text { atasnya sudah hilang. } \\
\text { Jumlah sandung satu } \\
\text { buah. }\end{array}$ & $\begin{array}{l}\text { Motif hias pada sandung ini tidak begitu te rlihat } \\
\text { karena bagian penyimpan tulang su dah hilang, } \\
\text { te tapi di ujung tiang pada sandung bertiang dua } \\
\text { masih te rlihat ukiran kedok dengan lidah yang } \\
\text { menjulur keluar. Pada salah satu tiang (sandung } \\
\text { bertiang satu) tersebut juga terdap at hia san } \\
\text { tumpal yang diukir bagus dan tatah an tangga } \\
\text { anwah berjajar tiga (tiga baris). Tidak dapat } \\
\text { diketahui siapa yang ada dalam sandung- } \\
\text { sand ung terseb ut. Diameter tiang sandung di } \\
\text { te mpat ini lu mayan besar sekitar } 20 \mathrm{~cm} \text {, dan } \\
\text { dalam kondisi yang sudah keropos. Sandung } \\
\text { berada di tepi Sungai Pajange idan berada di } \\
\text { satu kawasan. }\end{array}$ \\
\hline
\end{tabular}




\begin{tabular}{|c|c|c|c|c|c|}
\hline \multirow[t]{2}{*}{ No } & \multirow{2}{*}{$\begin{array}{c}\text { Kecamatan/ } \\
\text { Desa }\end{array}$} & \multicolumn{3}{|c|}{ Bentuk dan jumlah sandung } & \multirow[t]{2}{*}{ Letak, bahan dan motif hias } \\
\hline & & Bertiang satu & Bertiang dua & Bertiang empat & \\
\hline 4. & $\begin{array}{l}\text { Kecamatan } \\
\text { Tewah, De sa } \\
\text { Upun Batu }\end{array}$ & & & $\begin{array}{l}\text { Sand ung bertiang empat } \\
\text { berjumlah dua buah. } \\
\text { Satu sand ung masih } \\
\text { lengkap tiangnya, } \\
\text { satunya sudah tidak } \\
\text { memilik tiang lagi, tetapi } \\
\text { dari bentuk rumah } \\
\text { tulangya, diperkirakan } \\
\text { sandung ini dulunya } \\
\text { juga bertiang empat, } \\
\text { karena sudah rusak } \\
\text { maka tinggal rumah } \\
\text { tulangnya saja yang } \\
\text { kemudian ditempatkan } \\
\text { di atas bangunan } \\
\text { berundak dari beton. } \\
\text { Pada dind ingn ya } \\
\text { terdapat angka tahun } \\
\text { 1936. }\end{array}$ & $\begin{array}{l}\text { Motif hia s pa da tiang sandung be rupa hias } \\
\text { tu mpal dan takikan tangga arwah, sedangkan } \\
\text { pada rumah tulangnya sangat raya, dengan } \\
\text { ukiran su luran, patung manusia yang dileng kapi } \\
\text { dengan cat wama-warni. Pada bagian atap } \\
\text { sand ung juga dilengkapi dengan ukiran ukel di } \\
\text { bagian puncak atap. Selain itu, jug a dileng kapi } \\
\text { dengan hiasan ukiran pada bagian ujung atap, } \\
\text { baik yang mengarah ke depan maupun ke } \\
\text { samping. }\end{array}$ \\
\hline 5. & $\begin{array}{l}\text { Kecamata } \\
\text { Rungan } \\
\text { Hulu, Desa } \\
\text { Tumbang } \\
\text { Lapan }\end{array}$ & $\begin{array}{l}\text { Sandung bertiang satu } \\
\text { di de sa ini berjum lah } \\
\text { dua buah. Sandung } \\
\text { pertama hanya tinggal } \\
\text { tiang nya saja, kare na } \\
\text { te mpat penyimpan } \\
\text { tulang sudah tidak } \\
\text { ada. Diame er tiang } \\
\text { sekitar } 40 \text { cm dengan } \\
\text { tinggi (yang tersisa) } \\
\text { sekitar } 6 \text { meter. Tiang } \\
\text { sand ung ini terletak di } \\
\text { tepi jalan de sa } \\
\text { menghadap sungai } \\
\text { Lapan. Sand ung } \\
\text { kedua terletak di Kuta } \\
\text { Mapot (tempat tinggal } \\
\text { lama), dengan tempat } \\
\text { menyimpan tulangnya } \\
\text { berupa tempayan. } \\
\text { Diameter tiang juga } \\
\text { sekitar } 40 \text { cm }\end{array}$ & & & $\begin{array}{l}\text { Sandung be rtiang satu terbuat dari kayu ulin } \\
\text { dengan motif hias pada tiangn ya berupa } \\
\text { pahatan tangga arwah (sandung kedua) dan } \\
\text { bagian dari tubuh binatang melata yang } \\
\text { diukirkan terjuntai di dinding tiang (naga), yang } \\
\text { kelihatan hanya bagian badan dan ekor, bagian } \\
\text { kepala tidak ada (di sandung pertama). }\end{array}$ \\
\hline
\end{tabular}


Tabel 2. Sandung di hulu DAS Kahayan sesudah masa kemerdekaan

\begin{tabular}{|c|c|c|c|c|c|c|}
\hline \multirow[t]{2}{*}{ No } & \multirow{2}{*}{$\begin{array}{c}\text { Kecamatan/ } \\
\text { Desa }\end{array}$} & \multicolumn{4}{|c|}{ Bentuk dan jumlah sandung } & \multirow[t]{2}{*}{ Letak, Bahan, dan motif hias } \\
\hline & & Tidak bertiang & Bertiang satu & $\begin{array}{c}\text { Bertiang } \\
\text { dua }\end{array}$ & Bertiang empat & \\
\hline $1 \mathrm{a}$ & $\begin{array}{l}\text { Kecamatan } \\
\text { Kuala } \\
\text { Kunun, } \\
\text { Kelurahan } \\
\text { Tampang } \\
\text { Tumbang } \\
\text { Anjir }\end{array}$ & $\begin{array}{l}\text { Bentuk rumah } \\
\text { kecil, jumlah } \\
\text { satu buah, } \\
\text { sandung } \\
\text { dipugar pada } \\
30 \text { Juni } 2009 . \\
\text { Upacara tiwah } \\
\text { dilakukan } \\
\text { pada } 1970 .\end{array}$ & & & & $\begin{array}{l}\text { Berbahan beton, dengan hiasan } \\
\text { burung (tiga ekor) di atas atap. } \\
\text { Sandung ini diberi cat warna coklat, } \\
\text { kuning dan hijau. Terdapat tulisan } \\
\text { yang berisi nama orang yang ditiwah } \\
\text { dan dis impan dalam sandung ini. } \\
\text { Sandung ini berada di tepi jalan desa } \\
\text { yang sudah beraspal dan menghadap } \\
\text { ke Sungai Kahayan. Sandung ini } \\
\text { dikenal dengan nama sandung } \\
\text { Tamanggung Raden Binti. Tokoh } \\
\text { yang berada di sandungini } \\
\text { sebenarnya hidup pada masa } \\
\text { kolonial. }\end{array}$ \\
\hline $1 b$ & $\begin{array}{l}\text { Kecamatan } \\
\text { Kuala } \\
\text { Kunun, } \\
\text { Desa Petak } \\
\text { Bahandang }\end{array}$ & $\begin{array}{l}\text { Bentuk rumah } \\
\text { tulang kecil } \\
\text { beratap dan } \\
\text { tanpa tiang. } \\
\text { Jumlah } \\
\text { sandung } 15 \\
\text { buah. }\end{array}$ & $\begin{array}{l}\text { Bentuk rumah } \\
\text { tulang persegi } \\
\text { empat kecil } \\
\text { dengan ukuran } \\
\text { yang disesuaikan } \\
\text { dengan diameter } \\
\text { tiangnya. Tinggi } \\
\text { sandung ini } \\
\text { sekitar } 1 \text { meter. } \\
\text { Jumlah sandung } \\
\text { ini empat buah. } \\
\text { Didirikan pada } \\
2008 \text { (2), 2007, } \\
\text { dan 2009. }\end{array}$ & & 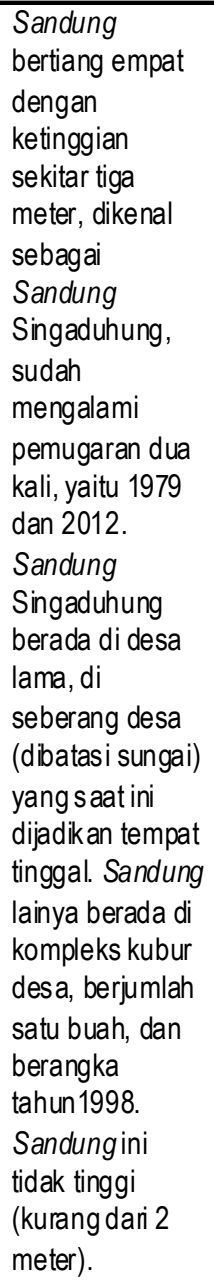 & $\begin{array}{l}\text { Sandung tanpa tiang terbuat dari } \\
\text { beton, dengan motif hias beragam } \\
\text { yang dibuat dengan cat berwarna. } \\
\text { Hiasan yang dibuat di dinding } \\
\text { sandung antara lain bunung, manusia, } \\
\text { flora, bintang, dan tempayan. } \\
\text { Sandung berada di kompleks kubur } \\
\text { desa, di tepi jalan besar yang } \\
\text { menghubungkan Palangkaraya dan } \\
\text { Kuala Kurun. Sandung bertiang satu } \\
\text { juga berada di kompleks kubur desa. } \\
\text { Bahan sandung bertiang satu ini } \\
\text { adalah beton dan kayu. Untuk yang } \\
\text { berbahan beton bagian tiang dan } \\
\text { tempat tulang menyatu. Bentuk tiang } \\
\text { dibuat menyerupai batang pohon. } \\
\text { Motif hias juga digambar (teknik lukis) } \\
\text { dengan menggunakan cat berwama, } \\
\text { antara lain flora suluran, bintang, dan } \\
\text { manusia.Sandung bertiang empat } \\
\text { juga dibuat dari kayu dengan motif } \\
\text { hias dilukis menggunakan cat } \\
\text { berwarna. Untuk Sandung } \\
\text { Singaduhung dilengkapi dengan } \\
\text { ukiran flora dan diberi cat } \\
\text { berwarna. Sandung di desa ini } \\
\text { menghadap ke arah Sungai Kahayan. }\end{array}$ \\
\hline
\end{tabular}




\begin{tabular}{|c|c|c|c|c|c|c|}
\hline \multirow[t]{2}{*}{ No } & \multirow{2}{*}{$\begin{array}{c}\text { Kecamatan/ } \\
\text { Desa }\end{array}$} & \multicolumn{4}{|c|}{ Bentuk dan jumlah sandung } & \multirow[t]{2}{*}{ Letak, Bahan, dan mo tif hias } \\
\hline & & Tidak bertiang & Bertiang satu & Bertiang dua & Bertiang empat & \\
\hline $1 \mathrm{c}$ & $\begin{array}{l}\text { Keca matan } \\
\text { Kuala Kurun, } \\
\text { Desa Teluk } \\
\text { Nyatu }\end{array}$ & $\begin{array}{l}\text { Berupa rumah } \\
\text { kecil tanpa tiang } \\
\text { dan terletak di } \\
\text { ujung desa. } \\
\text { Tinggin ya } \\
\text { sekitar } 1 \text { meter. } \\
\text { Sandung ini } \\
\text { tidak berangka } \\
\text { tahun, } \\
\text { menghadap ke } \\
\text { Sungai } \\
\text { Kahayan. }\end{array}$ & & & $\begin{array}{l}\text { Sand ung bertiang } \\
\text { empat ini tidak } \\
\text { terlalu tinggi, } \\
\text { terle tak te pat di } \\
\text { tepi Sungai } \\
\text { Kahayan dan } \\
\text { be rada di tengah } \\
\text { pe mukiman } \\
\text { penduduk. Tinggi } \\
\text { tiang sekitar } 1 \\
\text { meter dan } \\
\text { berangka tahun } \\
\text { 1988. }\end{array}$ & $\begin{array}{l}\text { Sandung tanpa tiang te rbuat dari beton, } \\
\text { dan seluruh din ding nya dicat wama biru, } \\
\text { dilengkapi dengan patung kecil di } \\
\text { depannya, dan hiasan ke lopak } \\
\text { bunga.Sandung be rtiang empat terbuat } \\
\text { dari kayu deng an hiasan yang cukup } \\
\text { raya, yaitu ukiran manusia, flora, burung } \\
\text { dan sedikit ukiran suluran pada ba gian } \\
\text { penyimpan tulang yang merupa kan } \\
\text { bagian dari pagar rumah. Hiasan san dung } \\
\text { ini dipercantik den gan cat yang berwama } \\
\text { wami. }\end{array}$ \\
\hline 2 & $\begin{array}{l}\text { Keca matan } \\
\text { Tewah, } \\
\text { Kelu rahan } \\
\text { Tewah }\end{array}$ & $\begin{array}{l}\text { Berupa rumah } \\
\text { kecil beratap } \\
\text { tanpa tiang, } \\
\text { menghadap ke } \\
\text { Sungai } \\
\text { Kahayan, dan } \\
\text { be rumlah } 29 \\
\text { buah. } 27 \text { buah } \\
\text { sandung berada } \\
\text { di kompleks } \\
\text { kubur sandung } \\
\text { Desa Tewah, } \\
\text { dua lainnya } \\
\text { be rada di } \\
\text { halaman } \\
\text { penduduk dan di } \\
\text { kuburan } \\
\text { muslimin. }\end{array}$ & $\begin{array}{l}\text { Jumlah tiga buah. } \\
\text { Sand ung milik Nyai } \\
\text { Balau, Laun, dan } \\
\text { Herwan, terletak di } \\
\text { kompleks kubur } \\
\text { sandung Desa } \\
\text { Tewah. Nyai Balau } \\
\text { ad alah seorang } \\
\text { tokoh wanita yang } \\
\text { hidup pada 1800-an } \\
\text { dan tempat awal } \\
\text { sandungnya berada } \\
\text { di Kuta Nyai Balau } \\
\text { tetapi kemudian } \\
\text { dipindahkan } \\
\text { be rsamaan dengan } \\
\text { diadakannya tiwah } \\
\text { masal pada } 1997 .\end{array}$ & $\begin{array}{l}\text { Tempat } \\
\text { tulang } \\
\text { berbentuk } \\
\text { persegi } \\
\text { panjang, } \\
\text { milik } \\
\text { masyara kat } \\
\text { biasa, dan } \\
\text { be rumlah } \\
\text { empat buah. } \\
\text { Tinggi tiang } \\
\text { sekitar } 2 \\
\text { me ter dan } \\
\text { diametemya } \\
10 \text { cm. } \\
\text { Sand ung ini } \\
\text { be rada di } \\
\text { areal } \\
\text { kompleks } \\
\text { sandung } \\
\text { desa dan } \\
\text { mengikuti } \\
\text { upacara } \\
\text { tiwah pada } \\
1997 .\end{array}$ & $\begin{array}{l}\text { Sandung bertiang } \\
\text { empat yang } \\
\text { be rada di } \\
\text { kompleks kubur } \\
\text { sandung berjumlah } \\
6 \text { buah. Satu buah } \\
\text { sandung milik } \\
\text { seorang tokoh } \\
\text { ma syarakat, yaitu } \\
\text { Dambung Rupuk } \\
\text { (dambung adalah } \\
\text { sebutan yang } \\
\text { setara dengan } \\
\text { pembekal) yang } \\
\text { hidup pada } 1918 . \\
\text { Sand ung ini dulu } \\
\text { be rada di Kuta } \\
\text { Nyai Balau, dan } \\
\text { saat diadakan } \\
\text { tiwah masal tahun } \\
\text { 1997, dipindahkan. } \\
\text { Empat buah } \\
\text { sandung lainnya } \\
\text { milik masyarakat } \\
\text { biasa. Ada dua } \\
\text { buah sandung } \\
\text { be rtiang empat } \\
\text { lainnya yang } \\
\text { ma sih berada di } \\
\text { sekitar Kuta Nyai } \\
\text { Balau. Salah } \\
\text { satunya adalah } \\
\text { milik Tamanggung } \\
\text { Kanyapi yang } \\
\text { ditiwah pada } 1916 \\
\text { dan direhab pada } \\
1965 . \text { Selain itu, } \\
\text { ada satu buah } \\
\text { sandung baru } \\
\text { bertiang empat, } \\
\text { dibangun tahun } \\
2013 .\end{array}$ & $\begin{array}{l}\text { Sandung tanpa tiang adalah sandung } \\
\text { milik masyarakat biasa yang dibuat dari } \\
\text { bahan beton. Motif hias pada dinding } \\
\text { sandung digam barkan dengan cat } \\
\text { berwarna, dengan bentuk hiasan antara } \\
\text { lain berupa uke/ (suluran), bintang, dan } \\
\text { bulan sabit. } \\
\text { Sandung bertiang satu milik Nyai Balau } \\
\text { dan L aun dibuat dari kayu ulin, } \\
\text { sedangkan sandung Herwan dibuat dari } \\
\text { beton. Motif hias tam pak lebih raya pada } \\
\text { sandung kayu, dilengkapi dengan ukiran } \\
\text { dan diberi cat berwa ma. Motif hias yang } \\
\text { meno njo l adalah penggambaran burung, } \\
\text { hias geometris, dan suluran. } \\
\text { Sandung bertiang dua se luruhnya dibuat } \\
\text { dari kayu ulin, dengan motif hias ukiran } \\
\text { dan penggamba ran deng an } \\
\text { meng gunakan cat berwama. Ragam motif } \\
\text { hiasnya antara lain tumpal (geometris), } \\
\text { manu sia, dan flora sulu ran. } \\
\text { Sandung bertiang empat semuanya juga } \\
\text { dibuat dari kayu, dengan motif hias ukir } \\
\text { yang dilengkapi dengan cat berwarna. } \\
\text { Motif hiasnya antara lain motif tum pal, } \\
\text { kedok dan tang ga arwah pada bagian } \\
\text { tiang, sedang kan bagian rumah kecilnya } \\
\text { dihiasi antara lain dengan motif ge ometris } \\
\text { (leng kung), sulu ran, dan manusia. Motif } \\
\text { kedok yang berwujud muka mahkluk } \\
\text { bermata bulat den gan lidah menjulur } \\
\text { keluar terdapat pa da dua sandung, salah } \\
\text { satunya milik Dambung Rupuk. } \\
\text { Sandung bertiang empat dari tahun } 2013 \text {, } \\
\text { dibuat dari beton, tiang dibuat menye rupai } \\
\text { batang pohon, dan diletakkan di atas } \\
\text { bangunan berundak. Motif hias pada } \\
\text { dinding sandung be rupa motif g eometris } \\
\text { yang dicat, serta dilengkapi degan satu } \\
\text { pot bunga artifisial di bagian depan. }\end{array}$ \\
\hline
\end{tabular}




\begin{tabular}{|c|c|c|c|c|c|c|}
\hline \multirow[t]{2}{*}{ No } & \multirow{2}{*}{$\begin{array}{c}\text { Kecamatan/ } \\
\text { Desa }\end{array}$} & \multicolumn{4}{|c|}{ Bentuk dan jumlah sandung } & \multirow[t]{2}{*}{ Letak, Bahan, dan motif hias } \\
\hline & & Tidak bertiang & Bertiang satu & Bertiang dua & Bertiang empat & \\
\hline 3 & $\begin{array}{l}\text { Kecamatan } \\
\text { Rungan, } \\
\text { Desa } \\
\text { Tumbang } \\
\text { Malahoi }\end{array}$ & $\begin{array}{l}\text { Sandung } \\
\text { tanpa tiang } \\
\text { milik Dodok } \\
\text { berada di } \\
\text { halaman } \\
\text { betang Toyoi, } \\
\text { dan } \\
\text { menghadap } \\
\text { ke Sungai } \\
\text { Kahayan. }\end{array}$ & $\begin{array}{l}\text { Sandung bertiang } \\
\text { satu be rum lah } \\
\text { dua buah, yaitu } \\
\text { sandung Siter } \\
\text { yang berada di } \\
\text { depan Betang } \\
\text { Toyoi, dan } \\
\text { sandung. Jumlah } \\
\text { sandung tanpa } \\
\text { tiang ada satu } \\
\text { buah. Biam ban } \\
\text { Bawai yang } \\
\text { berdiri megah di } \\
\text { halaman rumah } \\
\text { penduduk. }\end{array}$ & $\begin{array}{l}\text { Sandung bertiang } \\
\text { dua ada satu buah, } \\
\text { berada di sebelah } \\
\text { sandung satu tiang } \\
\text { Biamban Bawai. } \\
\text { Sandung ini juga } \\
\text { menghadap ke } \\
\text { Sungai Kahayan }\end{array}$ & $\begin{array}{l}\text { Sandung bertiang } \\
\text { empat ada dua } \\
\text { buah, yaitu } \\
\text { sandung Toyoi dan } \\
\text { sandung Bungai. } \\
\text { Sandung toyoi } \\
\text { berada di depan } \\
\text { betang Toyoi yang } \\
\text { saat ini mas ih } \\
\text { berdiri dengan } \\
\text { megah dan sudah } \\
\text { menjadi cagar } \\
\text { budaya yang } \\
\text { dilindungi. } \\
\text { Sandung Bungai } \\
\text { terletak tidak jauh } \\
\text { dari sandung } \\
\text { Toy oi, be rada di } \\
\text { halaman rumah } \\
\text { penduduk. Kedua } \\
\text { sandung } \\
\text { menghadap ke } \\
\text { sungai. }\end{array}$ & 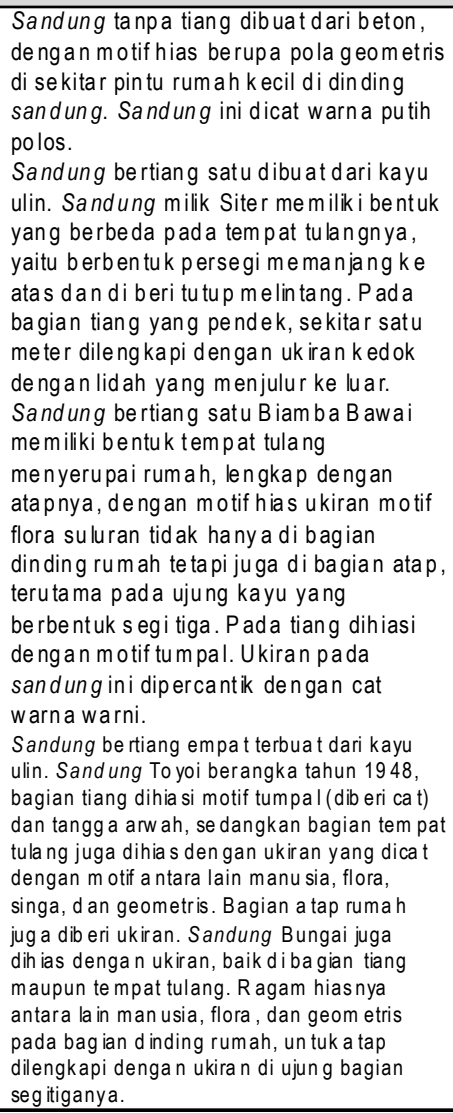 \\
\hline 4 & $\begin{array}{l}\text { Kecamatan } \\
\text { Rungan } \\
\text { Hulu, D esa } \\
\text { Tumbang } \\
\text { Lapan }\end{array}$ & & $\begin{array}{l}\text { Sandung be rtiang } \\
\text { satu ada satu buah, } \\
\text { terletak di sam ping } \\
\text { tiang sandung yang } \\
\text { besar, dan } \\
\text { menghadap ke } \\
\text { Sungai Lapan. } \\
\text { Tiang pen dek } \\
\text { dengan be ntuk } \\
\text { rumah penyimp an } \\
\text { tulangnya juga } \\
\text { memanjang ke ata s } \\
\text { dilegkapi dega } \\
\text { tutup (atap) }\end{array}$ & $\begin{array}{l}\text { Sandung bertiang dua } \\
\text { ada satu buah, milik } \\
\text { De se S yang } \\
\text { men inggal tahun } 1991 \\
\text { dan ditiwah pada } \\
2003 \text {. Tiangnya juga } \\
\text { pend ek de ngan ru mah } \\
\text { tulang yang kecil. }\end{array}$ & $\begin{array}{l}\text { Sandung bertiang } \\
\text { empat a da sa tu uah } \\
\text { dengan tiang yang } \\
\text { sangat pend ek. } \\
\text { Sandung ini milik } \\
\text { Ta manggung Jungkir } \\
\text { atau Ongko Gere k, } \\
\text { se orang toko h yang } \\
\text { disegani pada } \\
\text { masanya, yang } \\
\text { hidup pada zaman } \\
\text { ko lon ial (1 } 800 \text {-an ). } \\
\text { Te rletak di te pi jalan } \\
\text { desa dan } \\
\text { mengha dap ke } \\
\text { sungai. }\end{array}$ & $\begin{array}{l}\text { Sandung be rtiang satu dibuat dari kayu ulin, } \\
\text { dengan pa hatan tangg a arwah dan mo tif } \\
\text { tumpal pada ba gian tiang nya, tempat tulang } \\
\text { dib eri cat merah. } \\
\text { Sandung be rtiang dua juga dibuat dari ka yu } \\
\text { ulin den gan motif hias pada tiangnya berupa } \\
\text { tumpal dan tangga arwah, sedangkan di } \\
\text { bagian tempat tulan g berup a ukiran flora } \\
\text { suluran yang diberi cat berwarna. } \\
\text { Sandung be rtiang empa t juga dibu at dari } \\
\text { kayu ulin dengan motif hia stum pal dan } \\
\text { takikan tang ga arw ah pada ba gian tiang. } \\
\text { Untuk tempat tulangnya dileng kapi denga n } \\
\text { ukiran flo ra suluran, manusia, bin tang pada } \\
\text { bagian dinding, dan bag ian a tap ju ga dihia si } \\
\text { dengan ukiran terutam a di puncak a tap dan } \\
\text { uju ng atap yang me lintang. U kiran tersebut } \\
\text { dip ercantik dengan cat berwarna. }\end{array}$ \\
\hline 5 & $\begin{array}{l}\text { Kecamatan } \\
\text { Kahayan } \\
\text { Hulu Utara, } \\
\text { Kelurahan } \\
\text { Tu mbang } \\
\text { Miri }\end{array}$ & $\begin{array}{l}\text { Sandung tan pa } \\
\text { tiang berjumlah } \\
\text { e mpat buah, } \\
\text { te rletak di } \\
\text { kompleks } \\
\text { sand ung } \\
\text { Undeng. } \\
\text { Sandung } \\
\text { te rsebut } \\
\text { m enghadap ke } \\
\text { Sungai Miri }\end{array}$ & & $\begin{array}{l}\text { Bentuk sandung } \\
\text { bertiang dua ada tiga } \\
\text { buah, yaitu Undeng, } \\
\text { Batu, dan Teweng. } \\
\text { Ketiganya terletak di } \\
\text { tempat yang berb eda, } \\
\text { tetap i arah hadap nya } \\
\text { sama, yaitu ke Sungai } \\
\text { Miri. Sandung Tew eng } \\
\text { meng alam i pe rbaikan } \\
\text { dua kali, yaitu } 2005 \\
\text { dan } 2006\end{array}$ & & $\begin{array}{l}\text { Sandung tan pa tiang dibuat darib eton, } \\
\text { dengan } \mathrm{m} \text { otif h ias geome tris da n diberi cat } \\
\text { berwarna. } \\
\text { Sandung be rtiang dua dibuat dari ka yu, } \\
\text { dengan be ntuk rumah persegi empat (mirip } \\
\text { dengan bentuk rumah pada sandung b ertiang } \\
\text { empat). Jarak antartian g tid ak te rlalu jauh } \\
\text { seh ingg a bentuk tempa t tulan gnya juga } \\
\text { menyesuaikan. M otif h iasnya sangat raya, } \\
\text { dengan cara diukir dan dicat. M otif h ias di } \\
\text { tiang beru pa pahatan tumpal dan tangga } \\
\text { arwah, se dangkan motif hias di dind ing } \\
\text { rumah antara lain mo tif flora suluran, } \\
\text { manusia, tempayan. Motif hias di bagian atap } \\
\text { jug a diu kir da } n \text { dicat, dengan motif hias } \\
\text { berup a su luran dan bu rung pa da puncak } \\
\text { atap, serta ukiran di ujung atap yang } \\
\text { melintang (bag ian segitiga) }\end{array}$ \\
\hline
\end{tabular}

